\title{
Use of Highly Purified Porcine FSH Preparation for Superovulation in Japanese Black Cattle
}

\author{
Mikio SUGANO and Sigeru WATANABE \\ Fukushima Animal Husbandry Experiment Station, 18 Arai-Jizouhara, Fukushima 960-21, Japan \\ (Received 28 May 1996/Accepted 3 December 1996)
}

ABSTRACT. Fifty cattle were divided into 3 groups (I, II, III) according to FSH-R dosage used to induce superovulation between days 9 and 11 of the estrous cycle. Ova/embryo recovery rate did not differ significantly between groups I and II administered total dosages of 16 and $24 \mathrm{mg}$, respectively. However, the average number of recovered ova/embryos and transferable embryos was significantly lower in group III (administered a total dosage of $30 \mathrm{mg})(\mathrm{P}<0.05)$ than groups I and II. These results suggest that intramuscular administration of $16 \mathrm{mg}$ FSH-R over 3 days is sufficient for inducing superovulation in Japanese Black cattle. — KEY wORDs: FSH-R, Japanese Black cattle, superovulation.

J. Vet. Med.Sci. 59 (3): 223-225, 1997

Several hormone preparations, including a porcine pituitary extract preparation of follicle stimulation hormone (FSH) and pregnant mare's serum gonadotrophin (PMSG) have been used to induce superovulation. In addition, several studies have investigated the use of a gonadotrophin (GTH) preparation for the same purpose with varying results $[1,6,9,15]$. PMSG-treatment, which has a long half-life in the blood, is known to produce an antigen to the preparation after 2 or 3 treatment in cattle [16]. The FSH preparation, which has a shorter half-life, is widely used in Japanese Black cattle. Commercially available crude follicle stimulating hormone preparations (FSH-P) contain both FSH and luteinizing hormone (LH) activity $[3,5,14]$. Varying recovery rates of ova/embryos and transferable embryos in cows treated with FSH-P have been reported [7, 10, 12, 17]. Buckers [2] and Donaldson et al. [5] reported that these rates improved when pure porcine hypophyseal FSH (without LH) was administered.

A highly purified form of porcine FSH (FSH-R) has recently been derived from FSH-P in Japan. Isogai et al. [8] reported improved efficacy using FSH-R preparations in Holstein cattle. However few studies have reported the use of FSH-R in Japanese Black cattle.

The present study was performed in order to determine the optimal FSH-R dose and treatment regimen to induce superovulation.

Fifty Japanese Black cattle (aged 5 to 15 years; average weight $495 \mathrm{~kg}$ ) were examined for the presence of the corpus luteum (CL) by rectal palpation prior to initiating superovulation treatment between days 9 and 11 of the estrus cycle. FSH-R (Denka Pharmaceutical Co., Japan) was administered intramuscularly to each animal. Group I $(n=24)$ received 2 doses of $4 \mathrm{mg}$ each on the first day, 2 doses of $2.5 \mathrm{mg}$ on the second day, and 2 doses of $1.5 \mathrm{mg}$ on the third day for a total of $16 \mathrm{mg}$. Group II $(n=19)$ received 2 doses of $6 \mathrm{mg}$ each on the first day, 2 doses of 4 $\mathrm{mg}$ on the second day, and 2 doses of $2 \mathrm{mg}$ on the third day for a total of $24 \mathrm{mg}$. In an attempt to reduce the number of administrations, group III $(n=7)$ received a single dose of $10 \mathrm{mg}$ on each of the 3 days, for a total of $30 \mathrm{mg}$. Prostaglandin F2 alpha (Upjohn Co., Kalamazoo, MI) was administered to each of the animals 48 and $57 \mathrm{hr}$ after initiation of gonadotrophin treatment. A total dose of 35 $\mathrm{mg}$ was divided into doses of $25 \mathrm{mg}$ in the morning, and 10 $\mathrm{mg}$ in the afternoon. The treated cows were inseminated artificially with frozen semen from the Fukushima Animal Husbandry Experiment Station 57 and $72 \mathrm{hr}$ after the first injection of $\mathrm{PGF}_{2 \alpha}$. The experimental methods are summarized in Table 1. Ova and embryos were recovered nonsurgically on day 7 or 8 after the observation of estrus (day $0=$ estrus) by flushing with one liter of modified Dulbecco's phosphate-buffered saline (m-PBS) containing $3 \mathrm{~g}$ BSA. After flushing, the medium was recovered into embryo collection dishes, and the embryos were examined

Table 1. Experimental design and treatment regimen for FSH-R-induced superovulation

\begin{tabular}{|c|c|c|c|c|c|c|c|c|c|}
\hline \multirow{3}{*}{ Group } & \multirow{3}{*}{ Treatment } & \multirow{3}{*}{$\begin{array}{l}\text { No. of } \\
\text { Cattle }\end{array}$} & \multicolumn{7}{|c|}{ Timea) $^{\text {a) }}$ treatment } \\
\hline & & & \multirow{2}{*}{$\begin{array}{c}\text { Day } \\
\begin{array}{c}\text { Administra- } \\
\text { tion time }\end{array}\end{array}$} & \multicolumn{2}{|c|}{1} & \multicolumn{2}{|c|}{2} & \multicolumn{2}{|c|}{3} \\
\hline & & & & 8 & 17 & 8 & 17 & 8 & 17 \\
\hline I & $\begin{array}{l}\text { FSH } 16 \mathrm{mg} \\
\text { PGF }_{2} \text {-THAM } 35 \mathrm{mg}\end{array}$ & 24 & & $4 \mathrm{mg}$ & $4 \mathrm{mg}$ & $2.5 \mathrm{mg}$ & $2.5 \mathrm{mg}$ & $\begin{array}{l}1.5 \mathrm{mg} \\
25 \mathrm{mg}\end{array}$ & $\begin{array}{l}1.5 \mathrm{mg} \\
10 \mathrm{mg}\end{array}$ \\
\hline II & $\begin{array}{l}\text { FSH } 24 \mathrm{mg} \\
\text { PGF }_{2 \alpha} \text {-THAM } 35 \mathrm{mg}\end{array}$ & 19 & & 6 & 6 & 4 & 4 & $\begin{array}{c}2 \\
25 \mathrm{mg}\end{array}$ & $\begin{array}{c}2 \\
10 \mathrm{mg}\end{array}$ \\
\hline III & $\begin{array}{l}\text { FSH } 30 \mathrm{mg} \\
\text { PGF }_{2 \alpha} \text {-THAM } 35 \mathrm{mg}\end{array}$ & 7 & & 10 & & 10 & & $\begin{array}{c}10 \\
25 \mathrm{mg}\end{array}$ & $10 \mathrm{mg}$ \\
\hline
\end{tabular}

a) Treatment initiated between days 9 and 11 of estrus cycle. 
Table 2. Results of FSH-R-induced superovulation

\begin{tabular}{|c|c|c|c|c|c|c|c|c|}
\hline \multirow{2}{*}{ Group } & \multirow{2}{*}{$\begin{array}{l}\text { No. of } \\
\text { Cattle }\end{array}$} & \multirow{2}{*}{$\begin{array}{c}\text { No. of ova and } \\
\text { embryos collected }\end{array}$} & \multicolumn{5}{|c|}{ Proportion (\%) of ova/embryos by quality } & \multirow{2}{*}{$\begin{array}{c}\text { Rate of transferable } \\
\text { embryos }(\%)\end{array}$} \\
\hline & & & $\mathrm{A}$ & $\mathrm{B}$ & $\mathrm{C}$ & $\mathrm{D}$ & $\mathrm{E}$ & \\
\hline I & 24 & 153 & 59.5 & 9.2 & 3.9 & 17.6 & 9.8 & $73^{\text {a) }}$ \\
\hline II & 19 & 137 & 54.7 & 5.9 & 2.2 & 24.1 & 13.1 & $63^{\text {a) }}$ \\
\hline III & 7 & 30 & 30.0 & 13.4 & 3.3 & 23.3 & 30.0 & $47^{\mathrm{b})}$ \\
\hline
\end{tabular}

A: Excellent, B: Good, C: Fair, D: Degenerated embryo, E: Unfertilized ova.

a), b) Different superscripts indicate significant differences between the means $(\mathrm{P}<0.05)$.

Table 3. Comparison of embryo production resulting from different FSH-R treatment methods

\begin{tabular}{|c|c|c|c|}
\hline & group I & group II & group III \\
\hline No. of cattle & 24 & 19 & 7 \\
\hline $\begin{array}{l}\text { No. of ova/embryos } \\
\text { collected }\end{array}$ & 153 & 137 & 30 \\
\hline $\begin{array}{l}\text { No. of transferable embryos } \\
\text { (a) }\end{array}$ & $111(73)$ & $86(63)$ & $14(47)$ \\
\hline $\begin{array}{l}\text { Average No. of ova/embryos } \\
\text { collected }\end{array}$ & $6.4 \pm 5.3$ & $7.2 \pm 4.0^{\mathrm{c})}$ & $4.3 \pm 4.4^{\mathrm{d}}$ \\
\hline $\begin{array}{l}\text { Average No. of transferable } \\
\text { embryos }\end{array}$ & $4.6 \pm 5.2$ & $4.4 \pm 3.7$ & $2.0 \pm 4.1$ \\
\hline Average No. of $C^{b)}$ & $8.7 \pm 4.2$ & $8.2 \pm 3.8$ & $8.2 \pm 3.0$ \\
\hline
\end{tabular}

a) (No. of transferable embryos $) \div($ No. of ova/embryos collected $) \times 100$.

b) Rectal palpation, c), d) $\mathrm{p}<0.05$, Mean \pm SD.

under a stereomicroscope at 16 times magnification. Collected ova and embryos were transferred into m-PBS containing $20 \%$ calf serum for storage. Recovered embryos were evaluated according to morphological appearance and quality [11]. The number of CL was estimated by rectal palpation at the time of recovery. The data were analyzed using a Student's $t$-test and $\chi^{2}$-test.

In all fifty animals, ova and embryos were recovered at 7 or 8 days after onset of estrus. The results are summarized in Tables 2 and 3. In group I, which was treated twice daily for 3 days, the mean number of CL was $8.7 \pm 4.2$, that of ova/embryos was $6.4 \pm 5.3$, and that of transferable embryos was $4.6 \pm 6.2$. The transferable embryos rate was $73 \%$. In group II, which was treated twice daily for 3 days, the mean number of CL was $8.2 \pm 3.8$, that of ova/embryos was $7.2 \pm$ 4.0 , and that of transferable embryos $4.4 \pm 3.7$. The transferable embryo rate was $63 \%$. No significant differences were observed between groups I and II. On the other hand, in group III, which was treated once daily for 3 days, the mean number of CL was $8.2 \pm 3.0$, that of ova/ embryos was $4.3 \pm 4.4$, and that of transferable embryos was $2.0 \pm 4.1$. The transferable embryo rate was $47 \%$. The mean number of ova/embryos in group III was significantly lower $(\mathrm{P}<0.05)$ than that in group II. Moreover, the transferable embryo rate in group III was significantly lower $(\mathrm{P}<0.05)$ than in the other 2 groups. The highest rate of recovered embryos judged to be "excellent" was seen in group I (59.5\%), and the rates of degeneration and unfertilized ova were lowest in group I $(17.6 \%, 9.8 \%$, respectively). The highest number of unfertilized ova among all the groups was seen in group III $(30.0 \%)$. These factors did not differ significantly among the groups.

Isogai et al. reported that $36 \mathrm{mg}$ FSH-R was more effective than the same dose of FSH-P for inducing superovulation in Holstein cattle [8]. Similarly, Yamamoto et al. [21] reported that a FSH-R dose level of $20 \mathrm{mg}$ may be more effective in Holstein heifers. Furthermore McGowan et al. [13] studied the dose-response relationship for hMG in the range of $262.5 \mathrm{IU}-2,100 \mathrm{IU}$ for the superovulatory response in crossbred beef heifers and concluded that 1,050 IU hMG was the optimum dose of hMG. Higher doses of hMG resulted in embryos of poorer quality and an increased number of unfertilized ova.

The present study shows that superovulation can be successfully induced by administration of $24 \mathrm{mg}$ of FSH-R. Further reducing this dose to $16 \mathrm{mg}$ did not significantly reduce effectiveness. This suggests that FSH-R can effectively induce superovulation in Japanese Black cattle at a dose as low as $16 \mathrm{mg}$. Pawlyshyn et al. [18] reports that a higher dose of FSH (15 mg-60 mg) results in poorer quality embryos and a increased number of unfertilized ova. This could not be improved by increasing the FSH dosage further. Other studies have reported similar results for FSH$\mathrm{P}$ administration [19, 20].

Few studied have examined the effectiveness of once a day administration of a large dose of FSH-R compared to twice daily administration of a smaller dose [4]. The present study showed that a once daily administration of a large dose of FSH-R is not as effective as twice daily administration of a smaller dose. Further, this effect can be 
observed with a dose as low as $16 \mathrm{mg}$.

In conclusion, FSH-R can be used to induce superovulation in Japanese Black cattle at a $16 \mathrm{mg}$ dose injected intramuscularly twice daily for 3 days.

\section{REFERENCES}

1. Aoyagi, Y., Iwazumi, Y., Wachi, H., Oh, K., Takahashi, Y., Kanagawa, H., Miyamota, A., Umezu, M., and Masaki, J. 1987. Jpn. J. Anim. Reprod. 33: 167-172 (in Japanese).

2. Buckers, J. F. 1987. Theriogenology 27: 213 (Abstr.)

3. Chupin, D., Cobarnou, Y., and Procureur, R. 1984. Theriogenology 21: 223 (Abstr.).

4. Chupin, D. and Procureur, R. 1982. Theriogenology 17: 81 (Abstr.).

5. Donaldson, L. E., Ward, D. N., and Glenn, S. D. 1986. Theriogenology 25: 747-757.

6. Elsden, R. P., Nelson, L. D. and Seidel, G. E. Jr. 1978. Theriogenology 9: 17-19.

7. Goto, K., Ohkutsu, S., Nakanishi, Y., Ogawa, K., Tasaki, M., Inohae, S., Kawabata, S., Ishii, S., Miyamoto, A., Furusawa, T., Umezu, M., and Masaki, J. 1988. Theriogenology 29: 615-629.

8. Isogai, T., Arima M., Miyakoshi, S., and Watanabe, Y. 1992. J. Reprod. Develop. 38: j21-j25 (in Japanese).
9. Kanagawa, H. 1984. pp. 22-55. In: Transfer in Cattle. 1st ed., Kindai-Shuppan Tokyo (in Japanese).

10. Lerner, S. P., Thayne, W. V., Baker, R. D., Henschan, T., Meredith, S., Inskeep, E. K., Dailey, R. A., Lewis, P. E., and Butcher, R. L. 1986. J. Anim. Sci. 63: 176-183.

11. Lindner, G. M. and Wright Raymond, W. Jr. 1983. Theriogenology 20: 407-416.

12. Lindsell, C. E., Murphy, B. D., and Mapletoft, R. J. 1986. Theriogenology 26: 209-219.

13. McGowan, M. R., Braithwaite, M., Lochle W., and Mapletoft, R. J. 1985. Theriogenology 24: 173-184.

14. Murphy, B. D., Mapletoft, R. J., Manns, J., and Humphrey, W. D. 1984. Theriogenology 21: 117-125.

15. Nakahara, T., Doumeki, I., and Yamauchi, M. 1984. Jpn. J. Anim. Reprod. 30: 127-128 (in Japanese).

16. Nakajima, A., Hiraizumi, S., Onodera, K., Suzuki, H., Kudo, Y., and Domeki, I. 1992. J. Vet. Med. Sci. 54: 95-98.

17. Ohisa, N., Takada, N., Numabe, T., Yoshimura, I., and Ishikawa, Y. 1992. J. Jpn. Vet. Med. Assoc. 45: 471-475.

18. Pawlyshyn, V., Lindsell, C. E., Braithwaite, M., and Mapletoft, R. J. 1986. Theriogenology 25: 179 (Abstr.).

19. Sakakibara, H., Kudou, H., Shimizu, K., and Suzuki, T. 1993. J. Jpn. Med. Assoc. 46: 295-297.

20. Sunagawa, M. 1996. J. Reprod. Dev. 42: j55-j62.

21. Yamamoto, M., Ooe, M., Kawaguchi, M., and Suzuki, T. 1994. Theriogenology 41: 747-755. 